\title{
UNIVERSITY OF TEXAS AT AUSTIN RADIOCARBON DATES VII
}

\author{
S. VALASTRO, JR. and E. MOTT DAVIS \\ Radiocarbon Laboratory, Balcones Research Center, \\ The University of Texas at Austin
}

This list reports $\mathrm{C}^{14}$ measurements made in dating projects completed in the year ending December, 1968, and some measurements for projects still in progress. Age calculations are based on $\mathrm{C}^{14}$ half-life of $5568 \mathrm{yr}$ and a modern standard of $95 \%$ of NBS oxalic acid. Deviations reported are based on counting statistics of sample, background, and modern, and are $\pm l_{\sigma}$ except that when sample count approaches either modern or background, $2 \sigma$ limits are reported. The laboratory uses liquid scintillation counting of benzene, with $\mathrm{Li}_{2} \mathrm{C}_{2}$ and vanadium activated catalyst in preparation, as described in Texas IV (Radiocarbon, 1966, v. 8 , p. 453-466) and earlier lists. Chemical yields average $85 \%$.

Valastro is in charge of technical operations in the laboratory, and he and Davis share administrative responsibilities. Davis handles sample screening and archaeological appraisal, and has compiled this list.

\section{ACKNOWLEDGMENTS}

We acknowledge with gratitude the work of Alejandra G. Varela, Messeret Taddesse, and Christine Gevers in the preparation of samples, and the secretarial assistance of Fernanda Keeler and Mary Ann Hammond.

I. CHECK SAMPLES

\section{Tx-540. Greenwade House, B}

\section{A.D. 1830}

$120 \pm 50$

Wood from foundation post of Greenwade House, pioneer log cabin built in middle 1850's in Brazos R. valley near Whitney, Texas ( $31^{\circ} 54^{\prime}$ N Lat, $97^{\circ} 23^{\prime}$ W Long). Coll. 1950 by R. L. Stephenson; subm. by E. M. Davis. Not same specimen as one from same house dated Tx-43, $100 \pm$ 80 (Radiocarbon, 1964, v. 6, p. 140). Date represents average of 4 separate syntheses and counts. Individual runs are as follows, in cpm/gm: $9.33 \pm$ $0.07 ; 9.32 \pm 0.07 ; 9.29 \pm 0.06 ; 9.35 \pm 0.07$. Comment: agrees with Tx-43.

\section{Tx-541. Appleton, Wisconsin}

$11,620 \pm 80$

Spruce wood (Picea) from Appleton, Wisconsin, $14 \mathrm{ft}$ below plain of glacial Lake Oshkosh (44 $20^{\prime} \mathrm{N}$ Lat, $88^{\circ} 25^{\prime} \mathrm{W}$ Long). Should be same age as Two Creeks Forest Bed. Däte shown is average obtained from 3 pieces of sample, prepared and counted independently: 11,610 \pm 170 ; $11,700 \pm 170 ; 11,550 \pm 170$. Coll. by Wm. Read and subm. by R. J. Mason, Lawrence Coll., Appleton, Wisconsin. Comment: other dates pub. previously from same wood specimen are: Tx-44, 10,700 \pm 210 (Radiocarbon, 1964, v. 6, p. 141); Tx-269, 10,750 \pm 210 (Radiocarbon, 1966 , v. 8, p. 460 ; PIC-1, $12,000 \pm 300$ (Radiocarbon, 1965 , v. 7 , p. 202); 
FSU-3, 11,245 \pm 450 (Radiocarbon, 1966, v. 8, p. 48); ANU-5, 11,700 \pm 260 (Radiocarbon, 1967, v. 9, p. 18); ISGS-7; 11,500 \pm 300 (Radiocarbon, 1969, v. 11, p. 395). Another Appleton Two Creeks date, presumably from same find spot, is L-698D, 11,830 \pm 100 (Broecker and Farrand, 1963). Present date agrees with others except for Tx-44 and Tx-269 which appear too young.

\section{GEOLOGIC AND OCEANOGRAPHIC SAMPLES}

\section{A. Coast of Tamaulipas, Mexico}

\section{Carvajal Bluff series}

Marine shells (Busycon contrarium except where noted) from Carvajal Bluff, NE side Bahia Salada, 1 mi S of Carvajal, Tamaulipas, Mexico (24 $30^{\prime} \mathrm{N}$ Lat, $97^{\circ} 45^{\prime} \mathrm{W}$ Long). Samples are from Brown Sand (Behrens, 1966), a beach representing higher relative sea level. Dated to determine (a) number of submergences and (b) lateral variation within a single shell bed. Coll. 1967 and subm. by E. W. Behrens, Univ. of Texas Marine Sci. Inst., Port Aransas, Texas.

\section{Tx-542. Carvajal Bluff A}

$1780 \pm 70$

From $+3.35 \mathrm{~m}, 241 \mathrm{~m} \mathrm{~W}$ of ice house on peninsula between Laguna Madre and Bahia Salada.

\section{Tx-543. Carvajal Bluff B}

From $+2.53 \mathrm{~m}, 235 \mathrm{~m} \mathrm{~W}$ of ice house.

\section{Tx-544. Carvajal Bluff $\mathrm{C}$}
$1850 \pm 80$ A.D. 100

$1950 \pm 80$

A.D. 1 ice house.

\section{Tx-545. Carvajal Bluff D}

$3970 \pm 90$

From $+2.59 \mathrm{~m}, 241 \mathrm{~m} \mathrm{~W}$ of ice house. Shells have very little original color preserved, surfaces are slightly chalky. Relative sea level $+1.5 \mathrm{~m}$.

\section{Tx-546. Carvajal Bluff E}

$3710 \pm 90$

From $+2.44 \mathrm{~m}, 159 \mathrm{~m}$ W of ice house Shells very fresh; original colors well preserved. Relative sea level $+1.5 \mathrm{~m}$.

General Comment (E.W.B.): dates establish 2 high stands of Holocene sea level relative to Mexican E coast. Younger dates (Tx-542, 543, 544) correlate with previous dates from same sand (Tx-154, $2340 \pm 100$, Radiocarbon, 1965 , v. 7, p. 298; Tx-249, $1940 \pm 60$, Radiocarbon, 1966, v. 8, p. 457) and with a sample from Brazilian coast (A-21, van Andel and Laborel, 1964, $1750 \pm 170$, sea level $+1.4 \mathrm{~m}$ ); but they are younger than Abrolhos Terrace (2600 to 2100 B.P., sea level $+1.5 \mathrm{~m}$ ); (Fairbridge, 1961). Lack of widespread correlation makes it uncertain whether this deposit represents eustatic high sea level. Dates do not vary significantly 
with species or condition of shell. Older dates (Tx-545, 546), from stratigraphically lower part of unit, establish 2nd time of high relative sea level; their greater age is conformable with their position. They correlate well with high stand recorded on Brazilian coast (A-22, van Andel and Laborel, 1964, $3660 \pm 170$, sea level $+2.6 \mathrm{~m})$ and with postulated Younger Peron submergence of Fairbridge (1961, 3900 to 3500 B.P., sea level $+3 \mathrm{~m}$ ). Neither set of data correlates with dates from subsiding coasts, e.g., Gulf and Atlantic coasts of U.S.A. or NW coast of Europe; thus it is still uncertain whether these deposits represent local diastrophism or eustatic movements of sea level.

\section{Jamaica Sediment series}

\section{B. Jamaica}

Samples of coral from submarine sites, $\mathrm{N}$ coast of Jamaica, dated in study of age of framework growth and lithification of recent reefs and chronology of recent sea-level rise. Coll. 1968 and subm. by L. S. Land, Dept. of Geol. Sci., Univ. of Texas, Austin. $\delta \mathrm{C}^{13}$ values determined by Land, relative to Chicago Belemnite Standard (PDB).

$1940 \pm 90$

\section{Tx-667. Stairway Point, 95 ft} $\delta C^{14}=-214 \pm 7 \%$

A.D. 10

$\delta C^{13}=+0.51 \%$

From site $1 \mathrm{mi} \mathrm{W}$ of Runaway Bay Hotel (18 $27^{\prime} 12^{\prime \prime} \mathrm{N}$ Lat, $77^{\circ}$ $20^{\prime} 40^{\prime \prime}$ W Long). Montastrea annularis, $-95 \mathrm{ft}$, from blast in vertical cleft in reef, assoc. with recent lithification.

Tx-669. Discovery Bay Buoy, 85 ft $\delta C^{14}=-16 \pm 7 \%$

From site at T. F. Goreau diving buoy, Discovery Bay $\left(18^{\circ} 28^{\prime} 06^{\prime \prime}\right.$ $\mathrm{N}$ Lat, $77^{\circ} 24^{\prime} 48^{\prime \prime} \mathrm{W}$ Long). Depth $85 \mathrm{ft}, 3 \mathrm{ft}$ into tip of recent reef buttress, assoc. with massive shallow lithification. Error quoted is $2 \sigma$.

Tx-670. Rio Bueno, $135 \mathrm{ft}$

$$
\delta C^{14}=-650 \pm 4 \%
$$

$8410 \pm 140$

6460 в.c.

$\delta C^{13}=+3.38 \%$

From site just off Cricket Pitch, W side Rio Bueno Harbor (18 $28^{\prime}$ 25" N Lat, $77^{\circ} 27^{\prime} 45^{\prime \prime} \mathrm{W}$ Long). Brown $\mathrm{CaCO}_{3}$ crust from $135 \mathrm{ft}$ blast site. Vertical fractured cliff with minimal recent overgrowth.

\section{Tx-671. Rio Bueno, $70 \mathrm{ft}$}

$5670 \pm 90$ $\delta C^{14}=-510 \pm 4 \%$

3720 B.c.

$\delta C^{13}=+0.64 \%$

From same locality as Tx-670 (above). Diploria sp. from $70 \mathrm{ft}$ blast site, beneath recent overhang in vertical cliff.

General Comment (L.S.L.): all samples are limited in age by presently accepted curves for rise of recent sea level (Shepard, 1960). Tx-667, 670, 671 indicate reef growth did not keep pace with sea-level rise, nor did most recent framework growth take place at a past sea level. Also all 
samples are assoc. with recent lithification of reef sediments by precipitation of intergranular crystalline $\mathrm{CaCO}_{3}$ cements. Modern age of Tx-669 demonstrates extreme rapidity of lithification hitherto regarded (Fischer and Garrison, 1967) as rare and unimportant.

\section{Lacustrine Carbonate Samples, West Texas}

Lacustrine carbonate from 2 localities in playa of Mound Lake, Terry County, Texas (33 $14^{\prime} \mathrm{N}$ Lat, 102 ${ }^{\circ}$ 05' W Long). Coll. 1967 and subm. by C. C. Reeves, Jr., Dept. Geosci., Texas Tech. College, Lubbock, Texas.

\section{Mound Lake Core series}

Samples from 3 cores at $\mathrm{N}$ edge of playa. Core 1 is $50 \mathrm{ft} \mathrm{E}$ of Oscar Roberts' house; Core 2 just $\mathrm{N}$ of dunes and ca. 100 yds $\mathrm{N}$ of Core 1; Core $3 \mathrm{~N}$ of dunes and ca. $220 \mathrm{yds} \mathrm{N}$ of Core 2.

\section{Tx-549. Mound Lake Core $1 / 11$}

Core 1, $11 \mathrm{ft}$ depth.

Tx-550. Mound Lake Core 1/15 1/2

Core 1, 151/2 ft depth.

Tx-551. Mound Lake Core 2/26

Core 2, $26 \mathrm{ft}$ depth.

\section{Tx-552. Mound Lake Core $3 / 7$}

Core 3, $7 \mathrm{ft}$ depth.
$18,050 \pm 540$ 16,100 в.C.

$$
>\mathbf{3 7 , 0 0 0}
$$

$$
26,790 \pm 2540
$$
24,840 B.C.

$16,720 \pm 320$

General Comment (C.C.R.): dates indicate Mound Lake dolomite is of pre-Tahoka age, that Series II dunes are somewhat younger than 14,000 yr B.P., and that carbonate of Ruh Lake age exists in the area.

\section{Mound Lake Carbonate-pair series}

Dolomite and calcite assoc. with carbonate (indurated dolomite) lens, $\mathrm{W}$ edge of playa, $\mathrm{N}$ of oil-well access road in second drainage influent. This is the only co-existing pair of lacustrine carbonates so far found in lake basins in this area.

Tx-547. Mound Lake JL-4, dolomite

$27,720 \pm 1070$

Lacustrine carbonate (dolomite) at top of indurated dolomite.

$34,510 \pm 2490$

Tx-548. Mound Lake JL-1, calcite 32,560 в.C.

Lacustrine carbonate (calcite) at base of indurated dolomite. General Comment (C.C.R.): dates show correlation of exposed indurated dolomite lenses of Mound Lake to those in N, T-Bar Lake basin (0-2264, $26,000 \pm 1250$, Reeves, pers. commun.), and to carbonate in Mound Lake Core 2/26 (Tx-551, above). 
III. PALEOBOTANICAL SAMPLES

\section{Hershop Bog series, Texas}

Samples of peat from 5 cores in Hershop Bog, on Fred Alex farm, 2 mi SW of Ottine, Gonzales County, Texas (29॰ $35^{\prime} \mathrm{N}$ Lat, 97 $36^{\prime} 30^{\prime \prime}$ W Long), ca. $55 \mathrm{mi}$ ENE of San Antonio. Cores were from area $8 \mathrm{~m} \mathrm{sq}$. in deepest part of bog. Two other cores taken from same area for pollen analysis showed following sequence: 5.4 to $4.7 \mathrm{~m}$ depth, Birch Pollen Zone, pluvial; sharp change at ca. $4.7 \mathrm{~m} ; 4.7$ to $2.8 \mathrm{~m}$, Maximum Grass Zone, possibly representing Altithermal times; 2.8 to $0.8 \mathrm{~m}$, Umbelliferae Pollen Zone, may indicate change in physical nature of bog or its vegetation rather than change in regional moisture; $0.8 \mathrm{~m}$ to surface, Oak-Mixed Grass Pollen Zone, slight shift to more mesic. Insufficient regional work has been done to know how closely this section reflects regional climatic sequence.

Earlier study in nearby Soefje Bog produced date of $7825 \pm 200$ (0-501, Graham and Heimsch, 1960, p. 753-759) from zone possibly corresponding to some part of Maximum Grass Pollen Zone at Hershop. However, specific correlation between the 2 bogs cannot yet be macle and significance of Soefje date is problematical.

Upper, middle, and lower samples were taken from each core, as shown, each sample being a $20 \mathrm{~cm}$ sec. Coll. 1967 by Patty and Valastro; subm. by T. S. Patty and D. A. Larson, Dept. of Botany, Univ. of Texas at Austin.

Tx-553. Hershop Core A, Upper Core A, 0.3 to $0.5 \mathrm{~m}$.

Tx-554. Hershop Core A, Middle Core A, 2.3 to $2.5 \mathrm{~m}$.

Tx-555. Hershop Core A, Lower

Core A, 4.8 to $5.0 \mathrm{~m}$.

Tx-556. Hershop Core B, Upper Core B, 0.3 to $0.5 \mathrm{~m}$.

Tx-557. Hershop Core B, Middle

Core B, 2.3 to $2.5 \mathrm{~m}$.

Tx-558. Hershop Core B, Lower

Core B, 4.4 to $4.6 \mathrm{~m}$.

Tx-559. Hershop Core C, Upper

Core $\mathrm{C}, 0.3$ to $0.5 \mathrm{~m}$.
$2340 \pm 80$ 390 B.C.

$6150 \pm 130$ 4200 в.C.

$10,920 \pm 160$ 8970 в.c.

$1960 \pm 100$ 10 в.C.

$5980 \pm 100$ 4030 B.c.

$10,450 \pm 160$ 8500 в.c.

$2120 \pm 90$ 170 B.C. 
Tx-560. Hershop Core C, Middle $5850 \pm 120$

Core C, 2.3 to $2.5 \mathrm{~m}$.

3900 B.C.

Tx-561. Hershop Core C, Lower

$10,490 \pm 160$

Core C, 4.8 to $5.0 \mathrm{~m}$.

Tx-562. Hershop Core D, Upper

8540 в.c.

Core D, 0.3 to $0.5 \mathrm{~m}$.

$1520 \pm 80$

Tx-563. Hershop Core D, Middle A.D. 430

Core D, 2.3 to $2.5 \mathrm{~m}$.

Tx-564. Hershop Core D, Lower

Core D, 4.9 to $5.1 \mathrm{~m}$.

Tx-565. Hershop Core E, Upper

$6000 \pm 130$

4050 в.C.

Core E, 0.3 to $0.5 \mathrm{~m}$.

Tx-566. Hershop Core E, Middle

$10,560 \pm 160$

8610 B.c.

Core E, 2.3 to $2.5 \mathrm{~m}$.

$2170 \pm 90$

220 B.C.

Tx-567. Hershop Core E, Lower

$6050 \pm 100$

4100 в.c.

Core E, 4.9 to $5.1 \mathrm{~m}$.

General Comment (T.S.P.): dates are reasonably consistent from core to core, making upper level ca. 2000 B.P., middle level ca. 6000 B.P., lower level ca. 10,500 B.P. Sharp decline of forest tree types at ca. $4.7 \mathrm{~m}$ occurred ca. 10,000 yr ago, possibly relating to end of late-glacial pluvial period in S United States. More palynologic work is needed in this region before full significance of pollen profile and dates can be understood.

IV. ARCHAEOLOGIC SAMPLES: CADDOAN AREA

The following samples, mostly from Oklahoma, make up 2nd list (1st list was in Radiocarbon, 1968, v. 10, p. 390 ff.) from continuing dating project dealing with Caddoan archaeologic area in adjacent parts of Texas, Oklahoma, Arkansas, and Louisiana. Caddoan assemblages represent horticultural, village-dwelling peoples and are classed either as Gibson aspect, usually earlier, or Fulton aspect which extends into historic (post-A.D. 1600) peroid.

\section{A. Harlan Site, Oklahoma}

Charcoal samples from Harlan site (Ck-6), in Sequoia State Park, Cherokee County, Oklahoma $\left(35^{\circ} 55^{\prime} \mathrm{N}\right.$ Lat, $95^{\circ} 14^{\prime} \mathrm{W}$ Long). This is an early Gibson aspect Caddoan site. Some dates are averages of 2 separate preparations and counts, in which case the 2 dates are given in sample 
description. All samples subm. by R. E. Bell, Dept. Anthropol., Univ. of Oklahoma, Norman. Comments by Bell.

\section{Harlan site, Mound 3 series}

Mound 3 contained a large unidentified square rock feature with some interior flagstone areas.

\section{Tx-601. Harlan 16; Mound 3}

From underneath flagstones; apparently from mound fill forming integral part of mound. Coll. 1950 by R. E. Bell. $1180 \pm 60$ and 1390 \pm 70 .

\section{Tx-604. Harlan 19; Mound 3}

$$
1250 \pm 50
$$

From underneath rock layer forming $\mathrm{N}$ wall of large square at $\mathrm{NW}$ corner. Should be same age as Tx-601 (above). Coll. 1958 by T. Koehler. $1170 \pm 70$ and $1330 \pm 70$.

General Comment: dates agree with each other but are early in terms of other Harlan site dates. Mound Unit 3 is different from other mounds at Harlan and might represent earlier, unrecognized facet of occupation.

\section{Harlan site, Mound 4 series}

Mound 4 has 3 construction phases: House 3 (oldest) covered by Layer C, House 2 covered by Layer B, and House 1 covered by Layer A. Total height $4 \mathrm{ft}$. Coll. 1949 by L. Johnson.

\section{Tx-471. Harlan, Mound 4, Layer A} p. 239).

Should be same age as M-858, $610 \pm 75$ (Radiocarbon, 1963, v. 5,

\section{Tx-593. Harlan 8; Mound 4, A}

$$
860 \pm 70
$$

Layer A: charcoal from burning of House 1, or in fill overlying House 1 floor. Should be same as Tx-471 (above).

\section{Tx-470. Harlan, Mound 4, Layer B}

Should be same age as M-859, $820 \pm 75$ (Radiocarbon, 1963, v. 5, p. 239).

\section{Tx-588. Harlan 3; Mound 4, B}

$$
990 \pm 50
$$

Layer B: from burned House 2 or within fill overlying House 2. $990 \pm 70$ and $990 \pm 70$.

\section{Tx-589. Harlan 4; Mound 4, B}

$$
1050 \pm 50
$$

Layer B: as in Tx-588 (above), but from another excavation square. $1030 \pm 70$ and $1060 \pm 70$. 
Tx-590. Harlan 5; Mound 4, B

$$
1220 \pm 50
$$

Layer B: as in Tx-588 and Tx-589 (above), but from another excavation square. $1390 \pm 70$ and $1050 \pm 70$. Comment: date early in terms of other dates from Layer $\mathrm{B} ; 1050 \pm 70$ count more in agreement.

Tx-594. Harlan 9; Mound 4, B

Layer B: charcoal from burning of House 2, or in fill covering House 2.

Tx-597. Harlan 12; Mound 4, B $1100 \pm 50$

Layer B: $1030 \pm 60$ and $1170 \pm 70$. A.D. 850

Tx-586. Harlan 1; Mound 4, B or C

Layer B or C: from center post of either House 2 or House 3; probably House 2, at bottom of Layer B.

Tx-596. Harlan 11; Mound 4, B or C

A.D. 1050

$900 \pm 70$

Layer B or C: as in Tx-586 (above), but another center post from another excavation square. Probably House 2.

Tx-587. Harlan 2; Mound 4, $\mathrm{B}$ or $\mathrm{C}$

$960 \pm 50$

Layer B or C: large post, probably House 2 but possibly House 3. $970 \pm 70$ and $940 \pm 70$.

Tx-598. Harlan 13; Mound 4, B or $\mathrm{C}$

$840 \pm 60$

Layer B or C: $\log$, House 3 or House 2.

A.D. 1110

Tx-469. Harlan, Mound 4, Layer C

A.D. 1090

$860 \pm 70$

Layer C: might be part of same piece of wood as M-860, $775 \pm 75$ (Radiocarbon, 1963, v. 5, p. 239), but is more likely another piece from same structure.

Tx-591. Harlan 6; Mound 4, C

$980 \pm 50$

Layer C: charcoal from burning of House 3. $970 \pm 70$ and $990 \pm 70$.

Tx-592. Harlan 7; Mound 4, C

A.D. 1030

$920 \pm 70$

Layer C: charcoal from burning of House 3.

$960 \pm 40$

Tx-595. Harlan 10; Mound 4, C

A.D. 990

Layer C: charcoal from burning of House 3. $990 \pm 60$ and $920 \pm 50$. 
Tx-599. Harlan 14; Mound 4, C

Fill of Layer C: above House 3, below House 2. $1180 \pm 80$ and 1010 \pm 50 .

General Comment: considering all samples and their proveniences, construction dates may be suggested. House 1 and Layer A, A.D. 1100 to 1200; M-858 appears late. House 2 and Layer B, A.D. 1000 to 1120; Tx-590 appears early. House 3 and Layer C, A.D. 950 to 1050; M-64 appears early. Mound construction covers no more than $200 \mathrm{yr}$; this is also suggested by dates for Mound Unit 7 (see below).

\section{Harlan site, Mound 6 series}

Mound 6 covered a single house structure which had burned. Samples are from charred remains of structure. Coll. 1958 by R. E. Bell.

\section{Tx-603. Harlan 18; Mound 6}

Log no. 2, from collapsed roof or wall.

Tx-605. Harlan 20; Mound 6

Mixed sample, from several logs, all different from Tx-603 (above).

\section{Tx-607. Harlan 22; Mound 6}

Log no. 1 .

General Comment: dates agree with structural evidence that mound represents a single episode-burning of house and covering with mound. Overlap of $1_{\sigma}$ ranges suggests date of A.D. 1030 to 1050. These dates demonstrate value of samples derived from simple, tight associations.

\section{Harlan site, Mound 7 series}

Mound Unit 7 was built in 4 stages, called Mounds A (most recent) through D (oldest). Under Mound D was a structure on original ground surface; it had burned and some remains were included in lower Mound D fill. Coll. 1958 by R. E. Bell.

\section{Tx-606. Harlan 21; Mound 7, A}

Scattered charcoal from fill of Mound A. Should be same age as M-1092, $860 \pm 100$ (Radiocarbon, 1965, v. 7, p. 132). Comment: good agreement with M-1092.

Tx-610. Harlan 25; Mound 7, B

$970 \pm 70$

From fill of Mound B. Should be same age as M-1094, $1130 \pm 100$ (Radiocarbon, 1965, v. 7, p. 133). Comment: agrees with M-1094 within $1 \sigma$.

Tx-466. Harlan, Mound 7, B

$720 \pm 70$

From fill of Mound B.
A.D. 1230 
Tx-467. Harlan, Mound 7, Sub-D

$1020 \pm 50$

From fill below primary mound, Mound D. From same level came M-1093, $1360 \pm 100$ (Radiocarbon, 1965, v. 7, p. 132), which seems ca. 200 yr too early.

\section{Tx-608. Harlan 23; Mound 7, Sub-D}

A.D. 950

Burned debris under earliest stage, Mound D.

Tx-609. Harlan 24; Mound 7, Sub-D

$970 \pm 70$

Log beneath earliest stage, Mound D.

A.D. 980

General Comment: Mound A, in view of dates from lower mounds, should date ca. A.D. 1200 rather than A.D. 1100 date indicated here; reason for this discrepancy is not apparent. Mound B appears to date A.D. 11001200, and Mound D ca. A.D. 950-same time as lst construction of Mound Unit 4 at this site.

\section{Harlan site, Test Area 4 series}

Charcoal from burned remains of House 3 in Test Area 4, a spot in village where 2 superimposed house patterns were uncovered. Dates should be same as M-65, $720 \pm 200$ (Science, 1958, v. 128, p. 1120). Coll. 1950 by R. E. Bell.

\section{Tx-468. Harlan, Test 4, House 3, A}

Tx-600. Harlan, Test 4, House 3, B

Date is average: $910 \pm 60$ and $1010 \pm 70$.
$720 \pm 50$

A.D. 1230

A.D. 990

General Comment: charcoal was thought to be from later of 2 houses but earlier age of Tx-600 may indicate that both houses are involved, with construction taking place between A.D. 1000 and 1200; these dates agree with Unit 2 ( $\mathrm{Tx}-602$, below) and house under Mound Unit (Tx$603,605,607$, above) which are similar in form.

\section{Tx-602. Harlan 17; Unit 2}

$930 \pm 70$

A.D. 1020

From center post of house structure in Unit 2, an isolated house of village. House is similar in form to House 3 in Test Area 4 (Tx-458, Tx-600, above). Coll. 1949 by D. Wenner. Comment: date agrees with earlier date at Test Area 4 (Tx-600, above).

General Comment on Harlan site dates: main occupation of site begins ca. A.D. 950 and lasts to Ca. A.D. 1200. Most construction begins Ca. A.D. 950 to 1000 except that Mound Unit 3 is some $200 \mathrm{yr}$ earlier; this may turn out to represent a separate, earlier occupation. Dates of latest construction, in Mound Units 4 and 7 , are not as well established as beginning dates. 


\section{B. Other Oklahoma Caddoan Sites}

Samples subm. by R. E. Bell and D. G. Wyckoff, Univ. of Oklahoma. Comments by Wyckoff.

\section{Tx-611. Harvey site, Feature 5, B}

$550 \pm 60$

Charcoal from Feature 5 at Harvey site (Sq-18), $4 \mathrm{mi} \mathrm{W}$ and $5 \mathrm{mi}$ $S$ of Sallisaw, Oklahoma ( $35^{\circ} 22^{\prime} 45^{\prime \prime} \mathrm{N}$ Lat, 94 $52^{\prime} 10^{\prime \prime} \mathrm{W}$ Long). Feature 5 is bell-shaped pit with artifacts of Ft. Coffee focus, late Fulton aspect. Previous sample from same feature was Tx-486, $390 \pm 60$ (Radiocarbon, 1968, v. 10, p. 391). Coll. 1965 by Wyckoff. Comment: Harvey component seems earlier than Tyler (below, Tx-624, 625) in terms of artifact content; $\mathrm{C}^{14}$ dates support this inference.

Tx-612. Baldwin site, Feature 1, B

$680 \pm 70$

Charcoal from Feature 1, Baldwin site (Mc-84; Barr, 1965, p. 34-44) S side Long Creek 3/4 mi SE of Ringgold, McCurtain Co., Oklahoma, in Pine Creek Reservoir area (34 $12^{\prime} 45^{\prime \prime} \mathrm{N}$ Lat, 95 $06^{\prime} 00^{\prime \prime} \mathrm{W}$ Long). Feature 1 is trash pit with some shell-tempered pottery, believed part of Fulton aspect component. Another sample from same feature is Tx-490, $610 \pm 70$ (Radiocarbon, 1968, v. 10, p. 391). Coll. 1965 by Israel and Wyckoff. Comment: good agreement with Tx-490, but seems a little early for Fulton component.

\section{Tx-613. Bill Hughes site, Feature 2, B}

$570 \pm 60$

Charcoal from Feature 2 at Bill Hughes site (Mc-21), on ridge $\mathrm{N}$ of where Bee Creek enters flood plain of Mountain Fork R., McCurtain

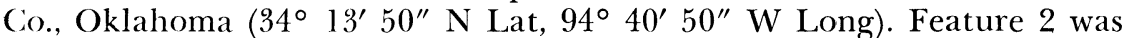
burned area with shale-tempered pottery typical of local early Fulton manifestations. Other samples from this feature are Tx-488, $540 \pm 60$ (Radiocarbon, 1968, v. 10, p. 390) and SM-887, $294 \pm 170$ (Wyckoff, 1967a, p. 7). Coll. 1964 by Wyckoff. Comment: Tx-613 and Tx-488 in close agreement; SM-887 seemingly more recent, but almost agrees within $1 \sigma$. Bill Hughes component closely resembles those at Beaver (Tx-626, below) and Woods Mounds ( $\mathrm{Tx}-475,491,492$, below), and similar $\mathrm{C}^{14}$ dates support this identification.

\section{Tx-619. Sheffield site, Feature 2}

$440 \pm 70$

Charcoal from Feature 2 at Sheffield site (Sq-22), $3 \mathrm{mi} \mathrm{S}$ and $2 \mathrm{mi}$ $\mathrm{W}^{\top}$ of Vian, Sequoyah Co., Oklahoma ( $35^{\circ} 27^{\prime} \mathrm{N}$ Lat, $95^{\circ} 00^{\prime} \mathrm{W}$ Long). Feature 2 was trash pit with shell-tempered pottery and other items characteristic of Fulton aspect occupation. Other samples from site are Tx-489, $790 \pm 200$ (Radiocarbon, 1968, v. 10, p. 391), felt to be too early for Fulton aspect, and WIS-256, $500 \pm 60$ (Radiocarbon, 1968, v. 10, p. 474), considered more appropriate in terms of archaeologic evidence. Coll. 1966 by Wyckoff. Comment: Tx-619 agrees with WIS-256 and with 
Tx-611, $550 \pm 60$ (this date list) from closely similar Harvey site. Tx-489 is clearly too early.

\section{Tx-626. Beaver site, Feature 3}

$600 \pm 80$

Charcoal from Feature 3 at Beaver site (Mc-1), directly $\mathrm{N}$ of old Hochatown bridge over Mountain Fork R., McCurtain Co., Oklahoma (34 $12^{\prime} \mathrm{N}$ Lat, 94 $41^{\prime} \mathrm{W}$ Long). Feature 3 was trash pit with shaletempered sherds common to local early Fulton aspect components. From House 3, just S of Feature 3, came Tx-479, $560 \pm 90$ (Radiocarbon, 1968, v. 10, p. 390). Coll. 1965 by Israel and Wyckoff. Comment: agrees with Tx-479. Beaver component closely resembles those at Bill Hughes ( $\mathrm{Tx}$ 613, above) and Woods Mounds (Tx-475, 491, 492, below). Beaver dates agree with dates from those sites.

\section{Woods Mound series}

Charcoal samples from Woods Mound group (Mc-104; Wyckoff, 1967b), $16 \mathrm{mi} \mathrm{N}$ and $9 \mathrm{mi} \mathrm{E}$ of Broken Bow, McCurtain Co., Oklahoma (34 $18^{\prime} \mathrm{N}$ Lat, 94 $41^{\prime} \mathrm{W}$ Long). Site believed to be early McCurtain focus, hence early Fulton aspect. Coll. 1964-5 by Wyckoff.

\section{Tx-491. Woods Mound BB}

$250 \pm 50$

Post from oval pattern underneath Mound BB. Date is average of 2 separate preparations and counts: $150 \pm 70$ (modern) and $360 \pm 70$.

\section{Tx-492. Woods Mound A}

$$
640 \pm 50
$$

Mound A, Feature 1, trash pit with shell-tempered pottery. Also from Mound A is SM-888, $159 \pm 147$ (Wyckoff, 1967a, p. 7), which is felt to be too recent. Date is average of 2 separate preparations and counts: $670 \pm 60$ and $610 \pm 70$.

\section{Tx-475. Woods Mound F}

$\mathbf{5 0 0} \pm \mathbf{5 0}$

Post 13 from irregular post pattern under fill of Mound F. Also from this mound is GaK-901, 710 \pm 80 (Wyckoff, 1967a, p. 7). Date is average of 2 separate preparations and counts: $460 \pm 70$ and $530 \pm 60$. General Comment: Tx-491 is inconsistently young. Tx-492 and Tx-475 agree well enough with GaK-901 and with dates from closely similar components at Bill Hughes site $(\mathrm{Tx}-613,570 \pm 60)$ and Beaver site (Tx-626, $600 \pm 80)$, both this clate list.

\section{Cat Smith series}

Charcoal samples from Cat Smith site (Ms-52), E side of Arkansas R., directly $\mathrm{N}$ of Webbers Falls Dam, $3 \mathrm{mi} \mathrm{NW}$ of Gore, Oklahoma $\left(35^{\circ} 34^{\prime} \mathrm{N}\right.$ Lat, $95^{\circ} 10^{\prime} \mathrm{W}$ Long). Single-component site, early Fulton aspect. Coll. 1965-6 by T. P. Barr. 
Tx-614. Cat Smith, House 2, B

A.D. 1150

$800 \pm 60$

Charred post in NW corner of House 2. Another post from same house dated $770 \pm 70(\mathrm{Tx}-493$, Radiocarbon, 1968, v. 10, p. 391), which was felt to be early.

\section{Tx-615. Cat Smith, House 1, A}

Charred $\log$ from House 1, Sq. 0-0 and 0-N1. House 1 is rectangular with 2 centerposts. Also from House 1 is WIS-254, $560 \pm 60$ (Radiocarbon, 1968, v. 10, p. 474).

\section{Tx-616. Cat Smith, House 1, B}

$630 \pm 60$

Another $\log$ from House 1 (see Tx-615, above), Sq. N1-L1 and N2-L1. General Comment: dates show good consistency but seem at variance with archaeologic data: (1) they all (especially those from House 2), seem too early for Fulton aspect material; (2) dates make House 2 significantly earlier than House 1, but archaeologic materials are same in both houses.

\section{Fine site, series 2}

Charcoal samples from Fine site (Sq-13), $4 \mathrm{mi} \mathrm{S}$ and $1.5 \mathrm{mi} \mathrm{E}$ of Vian, Sequoyah Co., Oklahoma (35 $26^{\prime} \mathrm{N}$ Lat, $94^{\circ} 57^{\prime} \mathrm{W}$ Long). Site has both late Gibson aspect and early Fulton aspect components. Previous series from this site was in Radiocarbon, 1968, v. 10, p. 390. Coll. 1967 by Wyckoff.

\section{Tx-617. Fine site, Trench $\mathrm{C}, 2$}

$$
920 \pm 60
$$

Charred post from incomplete house pattern in Trench C, Sq. N2-W3, with late Gibson aspect ceramics. From same pattern was Tx-485, 840 \pm 60 (Radiocarbon, 1968 , v. 10 , p. 390 ), which was felt to be too early for late Gibson. Comment: agrees with Tx-485, but still seems quite early.

\section{Tx-621. Fine site, House 1, B}

\section{A.D. 1170}

$780 \pm 60$

Charred $\log$ from House Pattern 1, small rectangular house in Trench I, early Fulton aspect. Comment: early Fulton should be later than this; clisagrees with other dates from house (see Tx-623, below).

Tx-623. Fine site, House 1, C

$620 \pm 80$

Charred $\log$ from House 1 in Trench I. Also from this house is Tx-519, $500 \pm 70$ (Radiocarbon, 1968, v. 10, p. 390); also see Tx-621 above. Comment: agrees with Tx-519.

General Comment: dates agree with archaeologic data in clearly indicating 2 components. 


\section{Tyler site series}

Charcoal obtained by flotation from trash pits in Tyler site (Hs-11), $7 \mathrm{mi} \mathrm{N}$ and 11/2 mi W of Keota, Haskell Co., Oklahoma (35 21' 40" $\mathrm{N}$ Lat, $94^{\circ} 56^{\prime} 35^{\prime \prime} \mathrm{W}$ Long). Materials in site indicate late Fulton aspect assignment. Coll. 1966 by Wyckoff.

\section{Tx-624. Tyler, Feature 5}

Feature 5 is trash pit in Graded Strip $H$.

\section{Tx-625. Tyler, Feature 12}

Feature 12 is trash pit in Graded Strip O.

General Comment: dates agree with each other and with archaeologic evidence for late prehistoric occupation.

\section{Horton site series}

Samples from trash pits at Horton site (Sq-11), 33/4 mi S of Vian,

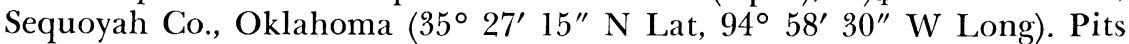
contained Fulton aspect material including shell-tempered pottery. Coll. 1967 by Wyckoff.

\section{Tx-627. Horton, Feature 1}

A.D. 1510

$\mathbf{4 4 0} \pm 90$

Charcoal and flotated material from Feature 1, trash pit in Trench D.

\section{Tx-618. Horton, Feature 2}

$780 \pm 70$ L.

Charred wood and hickory nuts from Feature 2, trash pit in Trench

General Comment: samples do not agree with each other. Tx-627 may be a little late, whereas Tx-618 is too early for context and associations. No archaeologic explanation is apparent for inconsistency.

\section{Werner Mound series, Louisiana}

\section{Louisiana}

Charcoal samples from charred remains of large oval structure underneath mound at Werner Mound site (16B08) on Willow Chute Bayou, $5 \mathrm{mi}$ NE of Bossier City, Bossier Parish, NW Louisiana (32 34' 30" $\mathrm{N}$ Lat, 93 $40^{\prime} 00^{\prime \prime} \mathrm{W}$ Long). Component assigned to Bossier focus, probably later part, but not latest as only $1.2 \%$ of sherds were shelltempered. Coll. 1958 and subm. by C. H. Webb, Shreveport, Louisiana.

Tx-478. Werner Mound, 3

$$
\mathbf{5 1 0} \pm \mathbf{7 0}
$$

Tx-628. Werner Mound, 2

$$
\begin{array}{r}
\text { A.D. } 1440 \\
880 \\
\text { A.D. } 1070
\end{array} \pm \mathbf{8 0}
$$

Tx-628 sample was split and parts were prepared and dated separately: $970 \pm 60,790 \pm 70$. Another part of this same sample was dated by Humble, 0-1132, $2050 \pm 110$ (Webb, pers. commun.). 
General Comment (E.M.D., S.V., Jr.): Tx-478 date is in accord with archaeologic evidence, but Texas and Humble dates on Tx-628 are so inconsistent that, as of now, site cannot be ascribed a radiocarbon age.

v. ARCHAEOLOGIC SAMPLES, GENERAL

A. Wallisville Reservoir, Texas Coast

Samples from sites in and near Wallisville Reservoir, Chambers Co., SE Texas, at mouth of Trinity R., E of Houston. Coll. 1966 and subm. by J. R. Ambler, Texas Archaeol. Salvage Project, Univ. of Texas, Austin.

\section{Wallisville $41 \mathrm{CH} 13$ series}

Paired charcoal and shell (Rangia) samples from Site 41CH13, stratified shell midden $1 \mathrm{mi} \mathrm{S}$ of Interstate Hwy 10 at Wallisville, $1 / 2 \mathrm{mi} W$ of Trinity R., in Mayes Marsh (29 $49^{\prime} \mathrm{N}$ Lat, $94^{\circ} 45^{\prime} \mathrm{W}$ Long). Site was first occupied in pre-pottery times; upper strata contain plain, sancltempered pottery of tentatively defined Lost River phase. Present samples should provide information on span of site occupation and aid in correlation of prehistoric river channels, shorelines, and aboriginal sites in Trinity R. delta.

\section{Tx-356. 41CH13/8, charcoal}

$2070 \pm 110$

\section{Tx-345. 41CH13/8, shell}

120 B.c.

330 B.c.

From Sq. M34 at junction of Strata 1 and 2, mostly at top of Stratum 1 which is sterile clay on which cultural debris rests. Samples should date earliest occupation of this part of site.

\section{Tx-343. 41CH13/6, charcoal}

$$
\begin{gathered}
1890 \pm 100 \\
\text { A.D. } 60 \\
1990 \pm 100 \\
40 \text { B.C. }
\end{gathered}
$$

Tx-341. 41CH13/6, shell

From hearth area, NE corner Sq. L34, Levels 13 and 14, elev. 97.80 to $98.00 \mathrm{~m}$ above site datum. This is a pre-pottery occupation. A bone projectile point was in same general stratum. Sample should provide date after which pottery appeared.

\section{Tx-344. 41CH13/10, charcoal}

Tx-342. 41CH13/10, shell

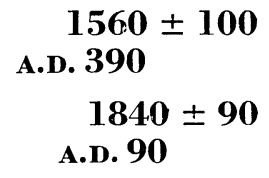

From Sq. 027, Level 4, elev. 98.30 to $98.40 \mathrm{~m}$ above site datum. Directly assoc. with earliest pottery in this part of site. Should help date beginning of pottery manufacture in this area. See general comment at end of Wallisville $41 \mathrm{CH} 16$ series, below.

\section{Wallisville $41 \mathrm{CH} 16$ series}

Paired samples (except Tx-395, Tx-398) of charcoal and shell (Rangia) from Site 4lCH16, shell midden $1 \mathrm{mi} \mathrm{S}$ of Interstate Hwy 10 
at Wallisville, $1 / 4 \mathrm{mi}$ W of Trinity R. (29 $49^{\prime} 30^{\prime \prime} \mathrm{N}$ Lat, $94^{\circ} 44^{\prime} 30^{\prime \prime}$ W Long). Contemporaneous with $41 \mathrm{CH} 13$ (above). Samples listed in stratigraphic order, oldest to most recent.

Tx-397. 41CH16/8, charcoal

$$
\begin{gathered}
2540 \pm 110 \\
590 \text { B.c. } \\
2150 \pm 60 \\
200 \text { B.c. }
\end{gathered}
$$

Tx-388. 41CH16/8, shell

From Sq. V33, Level 26, elev. 96.40 to $96.50 \mathrm{~m}$. Basal cultural layer in this part of mouncl. Tx-388 is average of separate syntheses and counts on 2 batches from same group of shells: $2010 \pm 90$ and $2280 \pm 80$.

Tx-395. 41CH16/19, charcoal

$$
2260 \pm 110
$$

310 B.C.

From Sqs. P15, Q15, in basal portion of midden in "Shell Stringer No. 1," thin shell layer separated from main body of deposit by sterile layer. Sample cannot be directly related stratigraphically to others from site but should be approximately contemporaneous with Tx-397.

\section{Tx-396. 41CH16/25, charcoal}

$1900 \pm 90$

Tx-389. 41CH16/25, shell

A.D. 50

$2240 \pm 90$

290 B.C.

From Sq. X33, Level 24, elev. 96.60 to $96.70 \mathrm{~m}$. From near base of midlen. Pre-pottery.

Tx-450. 41CH16/26, charcoal

$$
\begin{gathered}
2020 \pm 80 \\
70 \text { B.C. }
\end{gathered}
$$

Tx-460. 41CH16/26, shell

$2220 \pm 80$ 270 B.c.

From Sq. X33, Level 24, elev. 96.60 to $96.70 \mathrm{~m}$. Pre-pottery. Should agree with Tx-396.

\section{Tx-398. 41CH16/5, charcoal}

$1890 \pm 150$

From Sq. W 33, Level 24, elev. 96.60 to $96.70 \mathrm{~m}$. From near base of midden. Pre-pottery.

Tx-456. 41CH16/6, charcoal

$$
2010 \pm 90
$$$$
60 \text { B.c. }
$$

Tx-455. 41CH16/6, shell

$1950 \pm 70$

From Sq. U33, W quad., Level 26, elev. 96.40 to $96.50 \mathrm{~m}$ above site datum. Pre-pottery. Should agree with Tx-398.

Tx-399. 41CH16/1, charcoal

Tx-390. 41CH16/1, shell
$1740 \pm 100$

A.D. 210

$2010 \pm 90$

From Sq. V33, Level 22, elev. 96.80 to $96.90 \mathrm{~m}$. From near base of midden. Pre-pottery; stratigraphically above Tx-396, 397, 398. 


\section{Tx-449. 41CH16/3, charcoal}

$1950 \pm 80$

A.D. 1

Tx-457. 41CH13/3, shell

$2180 \pm 90$

230 B.C.

From Sq. V33, Level 23a, elev. 96.70 to $96.80 \mathrm{~m}$. Pre-pottery. Should agree with Tx-399.

\section{Tx-400. 41CH16/12, charcoal}

$1880 \pm 90$

A.D. 70

$2040 \pm 90$

Tx-392. 41CH16/12, shell

90 B.C.

From Sq. X33, Level 10. Lowest part of main pottery-bearing deposits.

\section{Tx-401. 41CH16/10, charcoal}

$1780 \pm 100$

Tx-393. 41CH16/10, shell

A.D. 170

$1890 \pm 90$

From Sq. X33, Level 7, elev. 98.30 to 98.33 m. Lowest part of main pottery-bearing deposits, but stratigraphically later than Tx-400.

\section{Tx-402. 41CH16/23, charcoal}

\section{Tx-394. 41CH16/23, shell}

$1400 \pm 110$

A.D. 550

$$
1810 \pm 90
$$

A.D. 140

From Sq. Q32, Feature 1, trash-filled pit at edge of midden; stratigraphically late, containing a good deal of pottery. Probably slightly later than $\mathrm{Tx}-401$.

General Comment on $41 \mathrm{CH} 13$ and $41 \mathrm{CH} 16$ dates (J.R.A.): samples show good internal consistency. Looking at charcoal samples alone, consistency within $41 \mathrm{CH} 16$ is further improved if one uses Tx-450, 456, 449, rather than Tx-396, 398, 399; former 3 were subm. later to check latter 3 which do not fit as well with remainder of series. Although both sites are contemporaneous archaeologically, dates indicate $41 \mathrm{CH} 16$ was occupied earlier. Dates shed light on crucial question of pottery introduction; first appearance at $41 \mathrm{CH} 16$ is ca. A.D. 100 (Tx-400, 401). At $41 \mathrm{CH} 13$ it is later (Tx-344) but only 1 date is available there; it might reflect later use of site by pottery-using peoples. Previous $\mathrm{C}^{14}$ dates assoc. with pottery in this area, on Rangia, are $0-911,1900 \pm 105$, and $0-912,3350 \pm 115$ (Ring, 1961); in light of present dates they now seem much too early. Pottery from present sites bears similarities to Tchefuncte pottery in Louisiana, and time span indicated for Lost River phase, A.D. 100 to A.D. 400-700, agrees with generally accepted time of late Tchefuncte in Louisiana (Gagliano, 1967). (S.V., Jr.): shells are older than charcoal by average of $1.36_{\sigma}$, except for Tx-397 and 388 pair, and Tx-456 and 455, in which relationship is inexplicably reversed. On average, shells were diluted with $1 \%$ to $3 \%$ dead carbon. Possibility is good that Rangia 
shell in this particular locality can be used for dating, taking into account a correction for this amount of dead carbon. However, more work is necessary.

\section{Wallisville 41CH20 shell series}

Samples of clam shells (Rangia) from S wall of Sq. A, Site 41CH20, in $\mathrm{E}$ bank of Old River Lake, $0.4 \mathrm{mi}$ S of Interstate Hwy $10\left(29^{\circ} 49^{\prime} 37^{\prime \prime}\right.$ $\mathrm{N}$ Lat, $94^{\circ} 47^{\prime} 30^{\prime \prime} \mathrm{W}$ Long). Tx-527 and Tx-528 assoc. with sherdtempered incised pottery of what has been called "Galveston Bay focus." Each sample divided into 2 parts which were prepared and counted separately; date is average; dates from separate counts are given in descriptions.

\section{Tx-527. 41CH20/4}

From $25 \mathrm{~cm}$ depth. Topmost heavy shell stratum. Both counts $840 \pm 80$.

Tx-528. 41CH20/5

From $40 \mathrm{~cm}$ depth. Middle shell stratum. $790 \pm 80$ and $850 \pm 80$.

\section{Tx-529. 41CH20/6}

$1550 \pm 60$

From $60 \mathrm{~cm}$ depth. Lowest shell stratum, assoc. with sand-tempered pottery, including 1 incised sherd from vessel found mostly in level above. $1490 \pm 80$ and $1600 \pm 80$.

General Comment (J.R.A.): taking into account that Rangia shells in this area may date several centuries older than charcoal (Wallisville $41 \mathrm{CH} 13$ and $41 \mathrm{CH} 16$ series, above), Tx-527 and Tx-528 help date Galveston Bay focus in late prehistoric times, but do not define its temporal limits. Tx-529 may be too early, as no Lost River phase pottery was found in site (see comments on $41 \mathrm{CH} 13$ and $41 \mathrm{CH} 16$ series).

\section{Tx-458. San Agustín de Ahumada}

$290 \pm 80$

Rangia shells from site of Presidio San Agustín de Ahumada (41CH53), $1.3 \mathrm{mi} \mathrm{NE}$ of Trinity R. at Wallisville, Texas $\left(29^{\circ} 50^{\prime} 40^{\prime \prime} \mathrm{N}\right.$ Lat, 94' 43' 30" W Long). Spanish occupation, A.D. 1766-1771 (Tunnell and Ambler, 1967). Dated to check validity of dates on shell in this area for this time span. Coll. 1967 by J. R. Ambler and subm. by Ambler and Valastro. Comment (S.V., Jr.): experience with older shell-charcoal pairs in same area (Wallisville 4lCH13 and 4lCH16 series, above) indicates that Rangia shells date older than charcoal by 100 to 400 yr. Present sample is at minimum end of this range.

\section{B. Cedar Bayou, Texas Coast}

Samples from 2 sites on Cedar Bayou, SE Harris Co., just $\mathrm{E}$ of Houston, Texas. Sites are reported by Ambler (1967). Coll. 1967 and subm. by J. R. Ambler. 


\section{Wright site shell series}

Clam shells (Rangia) from E wall, Sq. 1, Trench A, Wright site (41HR50), $100 \mathrm{yds}$ NW of Negrohead Lake, $400 \mathrm{yds} \mathrm{W}$ and $250 \mathrm{yds}$

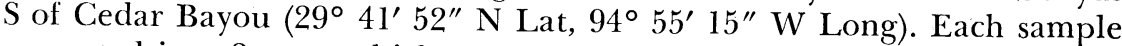
separated into 2 parts which were prepared and counted separately; date is average; dates from separate counts given in descriptions.

\section{Tx-530. Wright, 1}

$850 \pm 60$

From $40 \mathrm{~cm}$ depth. Topmost shell layer, with sherd-tempered incised "Galveston Bay focus" pottery. $860 \pm 80$ and $830 \pm 80$.

\section{Tx-532. Wright, 3b}

$1510 \pm 60$

From $70 \mathrm{~cm}$ depth. Lower shell layer, assoc. with pre-ceramic horizon, probably Late Archaic. Date should provide terminus post quem for appearance of pottery. $1550 \pm 80$ and $1470 \pm 80$.

General Comment (J.R.A.): Tx-530 agrees well with shell dates from nearby Wallisville $41 \mathrm{CH} 20(\mathrm{Tx}-527,840 \pm 60$, and Tx-528, $820 \pm 60$, this (late list) and Tx-533, $950 \pm 50$, from 41HR56 (below), indicating late prehistoric time for "Galveston Bay focus." Tx-532 seems much too recent, as pottery seems to appear in nearby Wallisville Reservoir area ca. A.D. 100 and Rangia dates in this area are usually falsely old (see comments on Wallisville 41CH13 and 41CH16 series, this date list).

\section{Cedar Bayou $41 \mathrm{HR} 56$ series}

Clam shells (Rangia) from E wall, Sq. 2, Site 4lHR56, W bank of

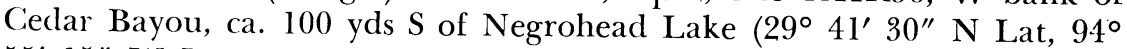
$55^{\prime} 15^{\prime \prime} \mathrm{W}$ Long). Each sample separated into 2 parts which were prepared and counted separately; date is average; dates from separate counts given in descriptions.

Tx-533. 41HR56/1

$950 \pm 50$

From $20 \mathrm{~cm}$ depth; top portion of shell deposit. Assoc. with "Galreston Bay focus" pottery. $980 \pm 70$ and $910 \pm 70$.

Tx-534. 41HR56/2

$$
1190 \pm 50
$$

From $35 \mathrm{~cm}$ depth. Central portion of shell deposit. Assoc. with earliest sand-tempered pottery, apparently just before introduction of sherd temper. $1120 \pm 60$ and $1260 \pm 70$.

\section{Tx-535. 41HR56/3}

$$
1840 \pm 50
$$

From $55 \mathrm{~cm}$ depth. Bottom portion of shell deposit. Preceramic, presumably Late Archaic. $1840 \pm 70$ and $1830 \pm 70$.

General Comment (J.R.A.): Tx-533 agrees well with shell dates Tx-530 from Wright site (above) and Tx-527 and Tx-528 from nearby Wallisville area $41 \mathrm{CH} 20$ (this date list). Tx-534 is only date now applicable 
to time of introduction of sherd temper, and therefore of beginning of "Galveston Bay focus;" in view of tendency of Rangia in this area to give dates 100 to $400 \mathrm{yr}$ earlier than charcoal (Wallisville $41 \mathrm{CH} 13$ and 41 CH16 series, this date list), actual date is presumably very late in 1st millennium A.D. Same consideration regarding shell dates makes Tx535 seem late, judging from Wallisville $41 \mathrm{CH} 13$ and $41 \mathrm{CH} 16$ dates. However, only a few Lost River-phase sherds were found at Cedar Bayou sites, possibly indicating later survival of preceramic horizons in this locality.

\section{Amistad Reservoir, Southwest Texas}

Samples from sites in Amistad Reservoir area, on Rio Grande and tributaries in vicinity of mouth of Pecos R., Val Verde Co., Texas. All samples subm. by personnel of Texas Archaeol. Salvage Project, Balcones Research Center, Univ. of Texas, Austin.

\section{Arenosa Shelter, Series 2}

Charcoal from Arenosa shelter (4lVV99), on right bank of Pecos R., $1 \mathrm{mi}$ upstream from confluence with Rio Grande $\left(29^{\circ} 42^{\prime} \mathrm{N}\right.$ Lat, $101^{\circ}$ $22^{\prime} \mathrm{W}$ Long). For previous series from this site see Radiocarbon, 1967, v. 9, p. 444-5. Coll. 1967 and subm. by D. S. Dibble; comments by D.S.D.

\section{Tx-661. Arenosa 55, Stratum 2}

$1380 \pm 60$

Upper 1/2 of Stratum 2; Ensor and other late Archaic dart points as well as arrow points. Comment: somewhat older than anticipated on basis of such dates as those from Cammack Sotol Pit (Tx-227, $625 \pm 185$, Radiocarbon, 1966, v. 8, p. 460; Tx-361, $610 \pm 80$, Radiocarbon, 1968, v. 10, p. 398) and 5 dates from Dunlap Midden 1 varying from ca. 550 to 950 (Tx-310, 351,357, 358, 359, ibid., p. 396-397); but consistent with estimates of age of terminal Archaic within Amistad Reservoir area.

\section{Tx-537. Arenosa 24, Stratum 5}

$$
1910 \pm 70
$$

From top to bottom of Stratum 5, within $1 \mathrm{ft}$ sq. column. Late Archaic, Ensor and Frio points, mostly Ensor. Comment: consistent with stratigraphic situation relative to other samples from site.

\section{Tx-536. Arenosa 30, Stratum 7}

$2150 \pm 80$

From base of Stratum 7; Late Archaic, Ensor and Frio points. Comment: consistent with stratigraphic position relative to Tx-284, $1970 \pm 110$ (Radiocarbon, 1967, v. 9, p. 444) from top of Stratum 7; but same age as Tx-285, $2070 \pm 140$ (ibid.) from base of deeper Stratum 9 , possibly reflecting relatively rapid accumulation of cultural debris.

Tx-662. Arenosa 61, Stratum 22x

$3640 \pm 80$

From fill of hearth, Feature 15, within Stratum 22x. Middle Archaic, 
Langtry and other dart point types. Comment: consistent with cultural assocs. and with stratigraphic position relative to other samples from site.

Tx-538. Arenosa 31, Stratum 25A

$4430 \pm 80$

From hearth, Feature 10, on surface of Stratum 25A. Early Archaic, Pandale points. Comment: consistent with stratigraphic position and assocs.

\section{Tx-660. Arenosa 612, Stratum 30}

$4440 \pm 110$

Upper component of Stratum 30. Early Archaic, Pandale points. Comments: younger than expected in view of dates from higher Strata 25 and 25A: Tx-538 (above) and Tx-312, $4790 \pm 140$ (Radiocarbon, 1967 , v. 9, p. 445). (S.V., Jr.): possibly contaminated by growth of mold clue to having been collected and sealed when wet; but no mold was observed in lab.

\section{Tx-668. Arenosa 62, Stratum 38}

$9550 \pm 190$ 7600 B.C.

All levels of Stratum 38, oldest definite culture-bearing deposit recognized at site; unifacial flake tools, nothing diagnostic; deeper than strata with "Early Barbed" points. Comment: might be earlier than Early Archaic.

\section{Bonfire shelter, Series 3}

Charcoal samples from Hearth 1 (Feature 27) in Bone Bed 2 of Bonfire Shelter (4IVV218), stratified kill site in Mile Canyon just E of Langtry $\left(29^{\circ} 49^{\prime} \mathrm{N}\right.$ Lat, $101^{\circ} 33^{\prime} \mathrm{W}$ Long). Bone Bed 2 contained large extinct bison, Plainview and Plainview-like points, one Folsom point (Dibble and Lorraine, 1968, p. 29-40). Previous date series from this site are in Radiocarbon, 1964, v. 6 and 1965, v. 7. Coll. 1964 and subm. by D. S. Dibble.

\section{Tx-657. Bonfire 561}

$$
9920 \pm 150
$$

Tx-658. Bonfire 511

$10,100 \pm 300$

8150 B.C.

General Comment (D.S.D.): together with previous date from same hearth (TX-153, 10,230 \pm 160 , Radiocarbon, 1965, v. 7, p. 304), these dates all agree within $1 \sigma$ and provide reliable determination of age of hearth, ca. 8000 to 8300 B.c.

\section{Perry Calk series}

Charcoal samples from Perry Calk site (41VV87), on left bank of Rio Grande $5 \mathrm{mi}$ downstream from mouth of Pecos R. (29 $39^{\prime} 20^{\prime \prime}$ $\mathrm{N}$ Lat, $101^{\circ} 21^{\prime} 0^{\prime \prime} \mathrm{W}$ Long). Site included late Archaic (Ensor points) and Neo-American (arrowpoint) occupations. Coll. 1967 and subm. by M. B. Collins. 
Tx-620. Perry Calk 60

A.D. 1360

Hearth 4, in Level 2, Sq. N107/W90. Ensor period, at time of introduction of arrowpoints.

Tx-622. Perry Calk 72

$1290 \pm 50$

From $S 1 / 3$ of fill in Feature 6, large pit dug at approximate time of introduction of arrowpoints to site. Should be same age as Tx-620 (above). Date is average of 2 separate syntheses and counts: $1390 \pm 70,1190 \pm$ 70 .

Tx-629. Perry Calk 74

A.D. 1260

$690 \pm 50$

From basin of Hearth, Feature 1; beginning of site occupation, assoc. with Ensor dart points. Should be earlier than Tx-620 and Tx-622 (above). Date is average of 2 separate syntheses and counts: $680 \pm 70,690 \pm 60$. General Comment (M.B.C.): Tx-622 is out of sequence and earlier than current estimates of arrowpoint introduction (ca. A.D. 1000); probably represents intrusion of earlier charcoal in pit. Tx-620 and Tx-629 are slightly later than estimates of arrowpoint introduction but are well within expected time range (Johnson, 1964, p. 98).

\section{Techo Bajo series}

Samples from Techo Bajo shelter, on Rio Grande ca. $9 \mathrm{mi}$ upstream from mouth of Pecos R. $\left(29^{\circ} 45^{\prime} 30^{\prime \prime} \mathrm{N}\right.$ Lat, $101^{\circ} 25^{\prime} 30^{\prime \prime} \mathrm{W}$ Long). From thin fiber layer with Ensor point in probable assoc. and overlying Langtry point. Sq. N105/W100, elev. $98.6 \mathrm{ft}$ above site datum. Coll. 1967 and subm. by M. B. Collins.

\section{Tx-630. Techo Bajo 6, charcoal}

$$
\begin{aligned}
740 & \pm 60 \\
\text { A.d. } 1210 & \\
830 & \pm 40
\end{aligned}
$$

Tx-633. Techo Bajo 6, wood

A.D. 1190

Tx-633 date is average of 2 separate syntheses and counts: $760 \pm$ 60 and $900 \pm 60$. Comment (M.B.C.): dates are in agreement with scant archaeologic data from site; probably give good indication of age of fiber layer.

\section{Tx-570. Nopal Terrace 107}

$2850 \pm 80$ 900 B.C.

Charcoal from Nopal Terrace site (41VV301) N bank of Rio Grande $2.6 \mathrm{mi}$ upstream from mouth of Devil's R. $\left(29^{\circ} 28^{\prime} \mathrm{N}\right.$ Lat, $101^{\circ} 06^{\prime}$ W Long). From Zone 7a; mostly Montell projectile points; a few Shumla. Coll. 1967 and subm. by W. M. Sorrow, Texas Archaeol. Salvage Project, Univ. of Texas at Austin. Comment (W.M.S.): 7 other dates are assoc. with Montell points in Amistad Reservoir area, all on charcoal except as noted: Bonfire Shelter, Bone Bed 3-Tx-46, $2310 \pm 210$ (bone, Radiocarbon, 1964, v. 6, p. 153); Tx-47, $2810 \pm 110$ (bone, ibid., p. 154); Tx-106, $2780 \pm 110$ (ibid.); Tx-131, $2510 \pm 100$ (Radiocarbon, 1965, 
v. 7, p. 304); Arenosa shelter, Stratum 11-Tx-211, $2440 \pm 140$ (Radiocarbon, 1967, v. 9, p. 444); Tx-286, $2410 \pm 140$ (ibid.); Devil's Mouth Zone 9-Tx-571, 2790 \pm 80 (below). Tx-570 is in earlier part of this series, agreeing with fact that Shumla points suggest early rather than late Montell time.

\section{Tx-571. Devil's Mouth 703, Zone 9}

$$
2790 \pm 80
$$

\section{Charcoll trom Zone 9 of Devils Mouth site (4IVV188) at conflence} of Devil's R. and Rio Grande ca. $1 \mathrm{mi}$ above Amistad Dam $\left(29^{\circ} 27^{\prime}\right.$ $\mathrm{N}$ Lat, $100^{\circ} 03^{\prime} \mathrm{W}$ Long). Zone 9 is lowest zone with Montell points (Johnson, 1964, Table 2, p. 84-5). Coll. 1967 and subm. by W. M. Morrow. Comment (W.M.S.): present date is early in Montell date series (see comment for Tx-570, above), agreeing with early Montell stratigraphic position.

\section{Tx-663. Piedra Diablo 22}

$3080 \pm 90$

From Test Pit l, lower portion of Zone 2, Pied (4IVV263) left side Devil's Rotion of Zone 2, Piedra Diablo site Devil's $\mathrm{R}$ (29० $27^{\prime} \mathrm{Nath}$ of Devil's R. (29 $27^{\prime} \mathrm{N}$ Lat, $101^{\circ} 03^{\prime} \mathrm{W}$ Long). Marshall points assoc. Middle Archaic. Coll. 1965 by E. R. Prewitt and subm. by D. S. Dibble. Comment (D.S.D.): consistent with current estimates of age of Marshall point type.

\section{Smith Shelter, series 2}

\section{Smith Shelter, Central Texas}

Charcoal and snail shell samples from Smith Rock Shelter (41 TV 42) on Onion Creek S of Austin, Texas ( $30^{\circ} 12^{\prime} \mathrm{N}$ Lat, $97^{\circ} 43^{\prime} \mathrm{W}$ Long). Site, reported by Suhm (1957), has 11 layers, 3 components: Layer I (deepest), Transitional Archaic; upper Layer II through Layer IX, Austin focus; Layer X-XI, Toyah focus. Dated to check earlier series (Tx-21 through Tx-28; Radiocarbon 1964, v. 6, p. 145-146) which seemed too recent, and to compare charcoal and snail shell dates. Coll. 1954-55 and subm. by Dee Ann Suhm Story, Dept. of Anthropol., Univ. of Texas, Austin. Samples listed in order of increasing depth.

Tx-509. Smith 53, Layers X-XI, charcoal $240 \pm 70$

Sq. N4-N5, B-C, 0 to 6 in. depth. Mixed Layers X-XI, Toyah focus or modern.

\section{Tx-510. Smith 26, Layers X-XI, charcoal}

A.D. 1730

$$
220 \pm 70
$$

Sq. 0-N1, C-D; 0 to 6 in. depth. Toyah focus or modern.

Tx-504. Smith 37, Layers X-XI, charcoal

A.D. 1750

$200 \pm 70$

Sq. S1-S2, C-D; 0 to 6 in. depth. Toyah focus or modern.

\section{Tx-505. Smith 42, Layer $X$, charcoal}


Tx-499. Smith 46, Layer $X$, shell

$$
710 \pm 80
$$

A.D. 1240

Sq. S1-S2, C-D, 6 to 12 in. depth. Toyah focus or modern.

Tx-508. Smith 34, Layers IX-X, charcoal A.D. 1460

$490 \pm 80$

Tx-497. Smith 41, Layers IX-X, shell

$$
920 \pm 80
$$

Sq. SI-S2, G-D; 12 to 18 in. depth. Mixed Toyah and Austin foci.

Tx-514. Smith 25, Layer IX, charcoal A.D. 1500

$450 \pm 70$

Tx-500. Smith 29, Layer IX, shell

$990 \pm 80$

Sq. 0-N 1, C-D, 18 to 24 in. depth. Mainly Layer IX. Late Austin focus.

Tx-513. Smith 32, Layer VIII, charcoal

$680 \pm 80$

Tx-501. Smith 28, Layer VIII, shell

A.D. 1270

$1030 \pm 80$

Sq. 0-N1, C-D, 24 to 30 in. depth. Late Austin focus.

Tx-518. Smith 63, Layer VII, charcoal A.D. 1120

$$
830 \pm 70
$$

Tx-503. Smith 65, Layer VII, shell

$$
\begin{array}{r}
1370 \\
\text { A.D. } 580
\end{array}
$$

Sq. 0-N1, A-B, 34 to 39 in. depth. Austin focus.

Tx-512. Smith 52, Layers VI-VII, charcoal

Tx-502. Smith 48, Layers VI-VII, shell A.D. 1020

$$
930 \pm 60
$$

Sq. 0-N1, B-C, 35 to 41 in. depth. Austin focus.

Tx-506. Smith 43, Zone VI, charcoal

Tx-496. Smith 39, Layer VI, shell

Sq. 0-N1, C-D; 36 to 42 in. depth. Austin focus.

Tx-516. Smith 27, Layers V-VI, charcoal

A.D. 1210

$1180 \pm 80$ A.D. 770

A.D. 1010

$$
940 \pm 80
$$

$$
1250 \pm 80
$$

A.D. 300

$740 \pm 80$

$1570 \pm 80$

Tx-495. Smith 38, Layers V-VI, shell

A.D. 380

Sq. 0-N1, C-D; 42 to 48 in. depth. Austin focus.

Tx-507. Smith 44, Layers IV-III, charcoal 
Tx-498. Smith 45, Layers IV-III, shell

Sq. 0-N1, C-D; 48 to 54 in. depth. Austin focus.

Tx-511. Smith 60, Layer I, charcoal

Sq. 0-N1, C-D, 72 to 80 in. depth. Mainly Archaic, but possibly some Austin focus.

Tx-515. Smith 4, Layer I, charcoal

Sq. 0-S1, D-E; 78 to 84 in. depth. Transitional Archaic.

Tx-494. Smith 11, Layer I, shell

Sq. 0-S1, D-E, 78 to 84 in. depth. Transitional Archaic.

\section{Tx-517. Smith 35, Layer I, shell}

$1120 \pm 80$ A.D. 830

$$
2170 \pm 80
$$

220 B.c.

Sq. 0-S1, D-E; 84 to 90 in. depth. Transitional Archaic.

General Comment (D.A.S.): considering charcoal dates only, Toyah-focus dates in this series agree with those from Kyle site (Jelks, 1962, p. 97-98). Austin-focus dates are a little later than those from other sites (e.g., Kyle site; ibid.) but are more in agreement with other dates than were dates in Texas II series from Smith shelter; possibly late Austin focus is represented here. Tx-514, from highest layer assigned to Austin focus, either is anomalous or layer is mixed; or else focus assignment is wrong due to incorrect interpretation of affiliations of Eddy point type found in this layer. Both this series and Texas II series indicate rapid accumulation of middle part of deposits in shelter. Tx-515 from Archaic layer is more recent than the few other late Archaic dates from central Texas (Tx-233, $1865 \pm$ 95; Tx-234, $1940 \pm 110$; Radiocarbon, 1966, v. 8, p. 461) and overlaps with Austin-focus dates, but in present state of knowledge it still might be appropriate for late Archaic. (S.V., Jr.): several shell samples are twice as old as charcoal; others are not consistent. Dilution by dead carbon in shells varies from $4 \%$ to $10 \%$. More investigation of snail shell-charcoal pairs is in order in this environment, in which soil contains much $\mathrm{CaCO}_{3}$.

\section{E. Other Texas and Oklahoma Sites}

\section{Sotol site series, west Texas}

Charcoal from Sotol site (X41CX8; Lorrain, 1968, p. 14-29), at base of northernmost of 3 Red Bluffs, E side of Pecos R. between Sheffield and Iraan, Crockett Co., Texas (101 $49^{\prime} \mathrm{N}$ Lat, $30^{\circ} 46^{\prime} \mathrm{W}$ Long). Coll. 1967 and subm. by Dessamae Lorrain, Anthropol. Research Center, Southern Methodist Univ., Dallas, Texas.

\section{Tx-649. Sotol, lot 31}

$$
400 \pm 60
$$

From basin-shaped, rock-lined Hearth 1 at base of uppermost zone (Zone D). No artifacts in direct assoc., but in same level were Perdiz. 
point and potsherd. Should date transition from Perdiz to later arrowpoint types such as Fresno and Garza.

Tx-650. Sotol, lot 39

A.D. 1580

$370 \pm 60$

From under burned rocks in large hearth within Zone D. No artifacts in direct assoc., but in same level in same square were a Fresno and 2 Garza points, a burin, and several scrapers. Should date these recent point types. Should be later than $\mathrm{Tx}-649$.

General Comment (D.L.): other dates relating to Perdiz points are from Toyah focus of central Texas $300 \mathrm{mi} \mathrm{E}$ of Sotol site (Smith site, Tx-305, $370 \pm 70$, this date list; Kyle site, SM-498, $400 \pm 130$, and SM-501, 685 \pm 165 , Jelks, 1962, p. 97, where samples are called C-5 and C-8). Fresno and Garza points are cross-dated at ca. A.D. 1700 by Pueblo trade sherds at Pete Creek site $180 \mathrm{mi} \mathrm{N}$ of Sotol (Parsons, 1967, p. 76). Fresno points are also dated in late 18th century by French trade goods at Gilbert site $400 \mathrm{mi}$ ENE of Sotol site (Jelks, 1967). These dates, although from distant sites, indicate present dates give proper age for time of transition from Perdiz to stemless triangular points in this area.

\section{Chicken House series, north Texas}

Charred corn cobs from possible smoking pits within oval post mold pattern of house, Feature 20, at Chicken House site (X41C06) on low terrace $\mathrm{N}$ of Fish Creek, $2 \mathrm{mi} \mathrm{W}$ of Red R. and ca. $10 \mathrm{mi} \mathrm{NNW}$ of

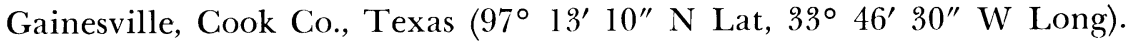
Site seems to represent an early Plains Village culture pattern. Coll. 1966 and subm. by Dessamae Lorrain, Anthropol. Research Center, Southern Methodist Univ., Dallas, Texas.

Tx-651. Chicken House 188

From Hole 4.

Tx-652. Chicken House 187

From Hole 5.

Tx-653. Chicken House 186

From Hole 23.

Tx-656. Chicken House 89

From Hole 24.

General Comments (D.L.): material complex at this site is intermediate in form, and hence is presumed to be intermediate in time, between late Woodland as represented at Pruitt site in Oklahoma and Henriettafocus sites in Texas (Krieger, 1946). Pruitt site $\mathrm{C}^{14}$ dates are GaK-899, $1220 \pm 90$, and GaK-900, $1140 \pm 90$ (Barr, 1966, p. 125). There are no Henrietta-focus $\mathrm{C}^{14}$ dates but closely related Washita-focus sites in Oklahoma have dates ranging from ca. 550 to 950 B.P. (Pillaert, 1963, p. 43) 
and Henrietta focus is presumed to be of same age. Therefore present dates, expected to be between these 2 date groups (i.e., 1000 to $1100 \mathrm{yr}$ old), are more than $300 \mathrm{yr}$ younger than expected. No archaeologic explanation for discrepancy is apparent. (E.M.D., S.V., Jr.): fractionation in corn might be responsible for discrepancy (Hall, 1967; Bender, 1968).

\section{Anaqua-site shell series, central Texas coast}

Shell samples (Rangia cuneata) from Anaqua site (41 JK 7), $8 \mathrm{mi}$ airline SE of $S$ edge of Edna city limits, on $E$ bank of Lavaca R., Jackson Co., Texas (28 $51^{\prime} 00^{\prime \prime} \mathrm{N}$ Lat, $96^{\circ} 35^{\prime} 00^{\prime \prime} \mathrm{W}$ Long). Site, reported by Story (1968, p. 43-67), contained discrete archaeologic complex including Scallorn and Granbury arrow points, sandy-paste pottery, compound fishhooks. Coll. 1967 and subm. by Dee Ann Story, Dept. Anthropol., Univ. of Texas, Austin. Depths given are below ground surface.

Tx-641. Anaqua 23

$2690 \pm 80$

Sq N100/W145, 0.5 to $0.6 \mathrm{ft}$ cleep.

740 B.c.

Tx-642. Anaqua 25

$5160 \pm 90$

Sq. N100/W145, 0.8 to $0.95 \mathrm{ft}$ deep.

Tx-643. Anaqua 39

3210 B.c.

Sq. N100/W140, $0.5 \mathrm{ft}$ deep.

Tx-644. Anaqua 40

$5200 \pm 90$ 3250 в.C.

Sq. N105/W130, surface to $0.7 \mathrm{ft}$ deep.

$5130 \pm 70$ 3180 B.C.

Tx-654. Anaqua 24

$3240 \pm 80$

Rangia sp., Sq. N125/W130, 0.5 to $1.0 \mathrm{ft}$ deep.

1290 B.C.

\section{Tx-655. Anaqua 38}

$2100 \pm 80$

Rangia sp., Sq. N100/W140, 0.2 to $0.4 \mathrm{ft}$ deep.

150 B.C.

General Comment (D.A.S., S.V., Jr., E.M.D.): lacking independent controls (e.g., charcoal samples) or other dates from this area, significance of these shell dates cannot yet be assessed. Arrow points indicate site is probably no more than $2000 \mathrm{yr}$ old. 3100 -yr spread of dates is at variance with archaeologic evidence of relatively brief occupation. Dates are recorded here so that they can be evaluated when archaeologic chronology of central Texas coast is better known.

\section{Tx-539. Burris \#1, southeast Texas}

$$
1070 \pm 70
$$

\section{A.D. 880}

Charcoal-stained soil from hearth in Area A-2, Burris \#1 site (McClurkan, 1968, p. 60), ca. 3 mi ESE of Onalaska, Polk Co., Texas, in

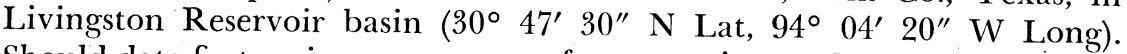
Should date first major appearance of arrow points and decorated pottery at site. Coll. 1966 by B. B. McClurkan and subm. by J. R. Ambler, Texas 
Archeol. Salvage Project, Univ. of Texas, Austin. Comment (E.M.D.): date, with several from Jones Hill site in same reservoir basin (Tx-325, $970 \pm 120$; Tx-336, $1410 \pm 190$; Radiocarbon, 1967, v. 9, p. 448), suggests that arrow points appeared in area late in 1st millennium A.D.

$\mathbf{5 2 0} \pm \mathbf{5 0}$

\section{Tx-524. Lee I site, Oklahoma}

A.D. 1430

Burned corn cobs and other charcoal from Lee site (Gv-3), 31/2 mi E of Lindsay, Garvin Co., Oklahoma, on N bank of Washita R. (34 $47^{\prime}$ N Lat, 97 $32^{\prime}$ W Long). From Grid A, Feature II, a pit from floor of Level 7 into sterile soil. Washita River focus, possibly early component. Coll. 1966 by Joe Winters and subm. by R. E. Bell, Dept. of Anthropol., Univ. of Oklahoma, Norman. Date is average of 2 separate preparations and counts: $520 \pm 50$ and $530 \pm 70$. Comments (R.E.B.): appears a little late in terms of other dates from Washita River focus, ranging from ca. 550 to 950 B.P. (Pillaert, 1963, p. 43), but is not outside range of probability in terms of archaeologic evidence. (E.M.D.): might be affected by fractionation in corn cobs (Hall, 1967; Benden, 1968), making it falsely young.

\section{F. Utah}

\section{Tx-452. Dust Devil Cave, Hearth 3}

$1820 \pm 80$

A.D. 130

Charcoal from Hearth 3 outside overhang of Dust Devil Cave (NA7613), 71/2 mi NE of summit of Navajo Mt., San Juan Co., Utah $\left(37^{\circ} 07^{\prime} \mathrm{N}\right.$ Lat, $110^{\circ} 47^{\prime} \mathrm{W}$ Long). Site had early pre-Basketmaker (Desha complex), Basketmaker II, and Pueblo III occupations. Hearth had no direct archaeologic assoc., but was morphologically like Basketmaker rather than Pueblo hearths. Coll. 1961 and subm. by J. R. Ambler, Univ. of Texas, Austin. Comment (J.R.A.): date indicates hearth dates from Basketmaker II period.

\section{Sand Dune Cave series}

Fragments of open-twined sandals of Desha complex, from lower portion of Stratum V, Sand Dune Cave (NA7523), 41/4 mi NE of summit of Navajo Mt, NE side of unnamed tributary of Cottonwood Creek, San Juan Co., Utah $\left(37^{\circ} 03^{\prime} \mathrm{N}\right.$ Lat, $110^{\circ} 48^{\prime} \mathrm{W}$ Long). Specimens are stratigraphically earlier than, and morphologically distinct from, typical Basketmaker II artifacts which are found in upper and middle portions of same stratum. Coll. 1961 and subm. by J. R. Ambler, Dept. of Anthropol., N. Ariz. Univ., Flagstaff, Arizona.

$7540 \pm 120$

Tx-448. Sand Dune Cave, A $\mathbf{5 5 9 0}$ B.C.

From Sq. P23-24, Level 4, bottom portion of Stratum V.

Tx-447. Sand Dune Cave, B 5750 в.C.

From Sqs. N23-24 and N20, Level 4. Bottom of Stratum V. 
Tx-454. Sand Dune Cave, $C$

From Sq. N19, Level 6. Stratum V.

5200 в.c.

Comment (J.R.A.): although in same stratum as Basketmaker II materials, dates are more than 5000 yr older than BM II. Lacking any comparable dated material, however, there is no reason now to question these ages for Desha complex.

\section{G. Latin America}

\section{Cueva Ahumada series, Nuevo Leon, Mexico}

Charcoal samples from Cueva Ahumada (NL-1), burned rock midden site, $1 \mathrm{mi} \mathrm{N}$ of Rinconada, Neuvo Leon, Mexico $\left(25^{\circ} 43^{\prime} \mathrm{N} \mathrm{Lat}, 100^{\circ}\right.$ $44^{\prime}$ W Long). Samples should date 1st occupation of site, below levels containing Clear Fork gouges, and give minimal age of pictographs buried by deposit. Depths given are below surface. Coll. 1966 by H. P. Jensen, Jr.; subm. by Jensen and J. F. Epstein, Dept. of Anthropol., Univ. of Texas at Austin.

Tx-572. Cueva Ahumada, Level 20(a)

$4440 \pm 90$

Sq. N10-E10, 200 to $210 \mathrm{~cm}$.

\section{Tx-573. Cueva Ahumada, Level 20(b)}

Sq. N8-E8, 200 to $210 \mathrm{~cm}$.

Tx-574. Cueva Ahumada, Level 21(a)

Sq. N8-E10, 210 to $220 \mathrm{~cm}$.

Tx-575. Cueva Ahumada, Level 21(b)

Sq. N10-E10, 210 to $220 \mathrm{~cm}$.

2490 B.c.

$3820 \pm 90$

1870 B.c.

Tx-576. Cueva Ahumada, Level 22

$4480 \pm 90$

2530 B.c.

Sq. N10-E10, 220 to $230 \mathrm{~cm}$.

General Comment (H.P.J., Jr., J.F.E.): except for Tx-573, all dates are in significant agreement, surprisingly so in view of amount of rodent burrowing in deposit. Anomalous Tx-573 date may be due to burrowing; it should probably not be used. Agreement of others indicates mixing of this part of deposit was minimal. These are 1st dates pertaining to rock art in this region; may help date similar styles found to $\mathrm{W}$ and NW in Mexico and Texas.

\section{Las Haldas series, Peru}

Charcoal from Las Haldas site, on Pacific coast $30 \mathrm{~km} \mathrm{~S}$ of Casma, Ancash Dept., Peru (9 $9^{\circ} 45^{\prime} \mathrm{S}$ Lat, $78^{\circ} 18^{\prime} \mathrm{W}$ Long). Site shows nonceramic occupation overlaid by strata containing pre-Chavín (Kotosh Waira-jirca/Kotosh Kotosh) and Chavín style pottery. Latest occupation was at time of breakdown of Chavin style. Coll. 1967; subm. by Terence Grieder, Dept. of Art, Univ. of Texas, Austin. 


\section{Tx-631. Las Haldas B}

Burned Tillandsia plants from several small fires $1 \mathrm{~m}$ above juncture of ceramic and non-ceramic deposits. Cut 1, Level 5, E flank Structure 4. Assoc. with pottery of pre-Chavín style, early construction of stone walls and mud floors.

Tx-648. Las Haldas A

$3140 \pm 80$

From Structure 6, Main Circle floor cut. From large ash lens on floor sealing non-ceramic levels. Dates beginning of construction of major buildings in center of site. Correlates with middle of Chavín style ceramic sequence.

Tx-632. Las Haldas C

From Structure 5 stairs; base of midden on top of floor. Dates beginning of brief reoccupation after hasty abandonment and brief hiatus. Correlates with final phase of Chavin style pottery.

General Comment (T.G.): these 3 dates span occupation of site by pottery makers, and agree with sequence of other dates from site: NZ-370-2, $3800 \pm 80$ (Engel, 1957) for late preceramic; GaK-607, $3590 \pm 130$ (Tokyo Daigaku, 1960, p. 518) for very early pottery level (before Tx631, above); GaK-606, $2690 \pm 150$ (ibid.) and NZ-370-1, $2500 \pm 100$ (Engel, 1966, p. 88) for final period of occupation, represented above by $\mathrm{Tx}-632$.

\section{H. Korea}

$6590 \pm 220$

Tx-440. Kum River, Korea

4640 B.c.

Charcoal from site on bank of Kum R., Korea, ca. $60 \mathrm{mi}$ from its mouth (36 $21^{\prime} \mathrm{N}$ Lat, $127^{\circ} 11^{\prime}$ E Long). From preceramic level at which hammerstones, anvil stones, points, etc., are found; believed to be more than $30,000 \mathrm{yr}$ old. Sample is from $4.6 \mathrm{~m}$ below current vegetation level which is at $+17 \mathrm{~m}$. Coll. 1965 by P. K. Sohn, Mus. Yonsei Univ., Seoul; subm. by S. M. Kim, Oak Ridge Inst. Nuclear Studies, Tennessee. Comment (S.M.K.): date unaccountably recent; sample may have been contaminated by younger material; site is inundated by river in rainy season.

REFERENCES

Date lists:
ANU I

FSU I
Michigan VIII
Michigan X
Packard I
Texas II
Texás III
Texas IV
Texas V
Texas VI
Wisconsin V

Polach et al., 1967

Stipp, Knauer, and Goodell, 1966

Crane and Griffin, 1963

Crane and Griffin, 1965

Kowalski, 1965

Tamers, Pearson, and Davis, 1964

Pearson et al., 1965

Pearson, Davis, and Tamers, 1966

Valastro, Pearson, and Davis, 1967

Valastro, Davis, and Rightmire, 1968

Bender, Bryson, and Baerreis, 1968 
Ambler, J. R., 1967, Three prehistoric sites near Cedar Bayou, Galveston Bay area: State Building Comm., Archeol. Program, rept. no. 8, Austin, Texas.

Barr, T. P., 1965, Three archaeological sites in the Pine Creek Reservoir, McCurtain County, Oklahoma: General Survey rept. no. 7, Oklahoma River Basin Survey Proj., Univ. of Oklahoma Research Inst., p. 1-85.

1966, The Pruitt site: Archaeol. Site rept. no. 5, Oklahoma River Basin Survey Proj., Univ. of Oklahoma Research Inst.

Bender, M. M., 1968, Mass spectrometric studies of Carbon 13 variations in corn and other grasses: Radiocarbon, v. 10, p. 468-472.

Bender, M. M., Bryson, R. A., and Baerreis, D. A., 1968, University of Wisconsin radiocarbon dates V: Radiocarbon, v. 10, p. 473-478.

Broecker, W. S. and Farrand, W. R., 1963, Radiocarbon age of the Two Creeks forest bed, Wisconsin: Geol. Soc. America Bull., v. 74, p. 795-802.

Crane, H. R. and Griffin, J. B., 1963, University of Michigan radiocarbon dates VIII: Radiocarbon, v. 5, p. 228-253. p. $123-152$.

Dibble, D. S. and Lorrain, Dessamae, 1968, Bonfire Shelter: Texas Memorial Mus., Misc. Papers no. I.

Engel, Frederic, 1957, Sites et établissements sans céramique de la côte Péruvienne: Soc. des Americanistes Jour., n.s., v. 46, p. 67-155. 1966, Geografia humana prehistorica y agricultura precolombina de la Quebrada de Chilca: Univ. Agraria, Lima.

Fairbridge, R. W., 1961, Eustatic changes in sea level, in: Physics and Chemistry of the Earth, v. 4, p. 99-185.

Fischer, A. G. and Garrison, R. E., 1967, Carbonate lithification on the sea floor: Jour. Geology, v. 75 , p. 488-496.

Gagliano, S. M., 1967, Late Archaic-Early Formative relationships in south Louisiana: Southeastern Archeol. Conf., Bull. 6, p. 9-22, Morgantown, West Virginia.

Graham, Alan and Heimsch, C. W., 1960, Pollen studies of some Texas peat deposits: Ecology, v. 41, p. 751-763.

Hall, Robert L., 1967, Those late corn dates: isotopic fractionation as a source of error in carbon-14 dates: Michigan Archaeologist, v. 13, no. 4.

Jelks. E. B., 1962, The Kyle site: Dept. of Anthropol., Univ. of Texas, Archaeol. ser. no. 5 .

(ed.), 1967, The Gilbert site: Texas Archeol. Soc. Bull., v. 37.

Johnson, LeRoy, Jr., 1964, The Devil's Mouth site: Dept. of Anthropol., Univ. of Texas, Archaeol. ser. no. 6.

Kowalski, S. J., 1965, Packard Instrument Company radiocarbon dates I: Radiocarbon, v. 7 , p. $200-204$.

Krieger, A. D., 1946, Culture complexes and chronology in northern Texas: Univ. of Texas publ. no. 4640.

Lorrain, Dessamae, 1968, Archeological excavations in northwestern Crockett County, Texas, 1966-1967: State Building Comm., Archeol. Program, rept. no. 12, Austin, Texas.

IrcClurkan, B. B., 1968, Livingston Reservoir, 1965-66: Late Archaic and Neo-American occupations: Texas Archeol. Salvage Project Papers, no. 12, Austin, Texas.

Parsons, M. L., 1967, Archeological investigations in Crosby and Dickens Counties, Texas, during the winter, 1966-1967: State Building Comm., Archeol. Program, rept. no. 7, Austin, Texas.

Pearson, F. J., Jr., Davis, E. M., and Tamers, M. A., 1966, University of Texas radiocarbon dates IV: Radiocarbon, v. 8, p. 453-466.

Pearson, F. J., Jr., Davis, E. M., Tamers, M. A., and Johnstone, R. W., 1965, University of Texas radiocarbon dates III: Radiocarbon, v. 7, p. 296-314.

Pillaert, E. E., 1963, The McLemore site of the Washita River focus: Oklahoma Anthrop. Soc. Bull., v. 11, p. 1-114.

Polach, H. A., Stipp, J. J., Golson, J., and Lovering, F. J., 1967, ANU radiocarbon date list I: Radiocarbon, v. 9, p. 15-27.

Ring, E. R., Jr., 1961, An evaluation of radiocarbon dates from the Galena site, southeastern Texas: Texas Archeol. Soc. Bull., v. 31, p. 317-325.

Shepard, F. P., 1960, Rise of sea level along northwest Gulf of Mexico, in: Shepard, F. P. et al. (eds.), Recent sediments of the northwest Gulf of Mexico: Am. Assoc. Petrol. Geologists, Tulsa, Oklahoma, p. 338-344. 
Stipp, J. J., Knauer, G. A., and Goodell, H. G., 1966, Florida State University radiocarbon dates I: Radiocarbon, v. 8, p. 46-53.

Story, Dee Ann, 1968, Archeological investigations at two central Texas Gulf coast sites: State Building Comm. Archeol. Program, rept. no. 13, Austin, Texas.

Suhm, Dee Ann, 1957, Excavations at the Smith Rockshelter, Travis County, Texas: Texas Jour. Sci., v. 9, p. 26-58.

Tamers, M. A., Pearson, F. J., Jr., and Davis, E. M., 1964, University of Texas radiocarbon dates II: Radiocarbon, v. 6, p. 138-159.

Tokyo Daigaku, 1960, Andes (1): the report of the University of Tokyo Scientific Expedition to the Andes in 1958, Tokyo.

Tunnell, C. D. and Ambler, J. R., 1967, Archeological excavations at Presidio San Agustin de Ahumada: State Building Comm., Archeol. Program, rept. no. 6, Austin, Texas.

Valastro, S., Jr., Davis, E. M., and Rightmire, C. T., 1968, University of Texas at Austin radiocarbon dates VI: Radiocarbon, v. 10, p. 384-401.

Valastro, S., Jr., Pearson, F. J., Jr., and Davis, E. M., 1967, University of Texas radiocarbon dates V: Radiocarbon, v. 9, p. 439-453.

van Andel, T. H. and Laborel, J., 1964, Recent high relative sea level stand near Recife, Brazil: Science, v. 145 , p. $580-581$.

Wyckoff, D. G., 1967a, Radiocarbon dates from Oklahoma River Basin Survey excavations: Oklahoma Anthropol. Soc. Newsletter, v. 15, no. 2. 1967b, Woods Mound group: Misc. rept. no. 1, Oklahoma River Basin Basin Survey, Univ. of Oklahoma. 